Per Anders Nordengen

Prest, forfatter, foredragsholder og samtaleveileder Foto: Calle Hut

\title{
Pjusk eller syk?
}

\author{
Er vi sykere enn $f \varnothing r$ ? Eller er det \\ innstillingen til hva sykdom er som \\ er forandret?
}

Det virker som flere enn noen gang sliter i dag med livet, selv om vi som befolkning aldri har hatt det bedre. På tross av materiell velstand strever mange med lettere psykiske helseproblemer. Dette er et av vår tids største paradokser, og det er en samfunnsutfordring som får store konsekvenser for dem som rammes og for deres pårørende.

Jeg tror ikke vi er sykere i dag enn tidligere. Kan noe av grunnen være at vi har fått et endret syn på hva som er sykt? Vi setter altfor raskt betegnelsen «sykdom» på det som egentlig er helt normalt. Alle vondter er ikke sykdom. Det er ikke unormalt å føle seg «utafor» og være deprimert av og til. Å ha vondt i hodet innimellom er helt vanlig. Vi må ikke kalle alt som er ubehagelig for sykdom, men i stedet alminneliggjøre at vi kan ha vondt både i følelsene og i kroppen av og til.

Før var det en dyd å være robust, og hardførhet var en viktig ballast å ha med seg i livet. I dag kan det virke som vi er skjørere enn før, og mye av det som tidligere var normalt, kalles i dag for sykdom. I min ungdom var det noen som var sjenerte. I dag ville en del av dem sannsynligvis fått diagnosen «sosial angst». Overivrige og hyperaktive barn kan i dag for raskt få diagnosen AD/HD. Jeg er redd for at all diagnostiseringen gjør folk sykere. Vi bør heller alminneliggjøre det at vi er forskjellige, og vi bør ha større romslighet overfor ulik atferd og personlighet. Alle problemer må ikke profesjonaliseres, og problemfrihet må aldri bli standarden.

Jeg undrer meg også over at det i dag er så mange som er slitne. Har livet virkelig blitt så slitsomt at vi behøver å bli syke av det? En sterkt økende psykisk plage er nettopp slapphet og slitenhet. Unders $\varnothing$ kelser viser at i løpet av de siste 12 år har fenomenet slitenhet økt med $70 \%$. Det er grunn til bekymring dersom vi som befolkning er mer slitne nå som vi aldri har hatt bedre forutsetninger for overskudd og godt liv. Ungdom kan få seg til å si at de «alltid er så slitne», og jeg har hørt barn i barnehagealder si at de er slitne eller stresset!

Når ble livet en sykdom? Vi trenger sterkere immunforsvar overfor livets uunn-

gåelige og ubehagelige påkjenninger, og vi må trene på å takle motgang. Vi må endre sykdomsbegrepet, heve smerteterskelen og normalisere slitasje og lettere sykdommer. Å ha det vondt er ikke livets hovedfarge, selv om det innimellom er en av livets mange farger.

$\emptyset$ kningen i bruken av piller for å løse livets utfordringer og plager sier mye om hva vi betrakter som friskt og sykt. Lykkepillebruken har $ø$ kt kolossalt de siste årene. Hver tredje jente i alderen 15-24 år har ifølge undersøkelser en pakke med smertestillende piller i vesken. Noen bruker også medisin for å takle krevende situasjoner.

Verdens Helseorganisasjon (WHO) har en definisjon av helse som jeg tror bidrar til at flere føler seg syke: «Helse er en tilstand av konstant (fullstendig) psykisk, fysisk og sosial velvære.» Da kjenner jeg ingen som er helt friske! Alle sliter av og til fysisk, psykisk eller sosialt. Denne definisjonen bør etter min mening endres, for den kan føre til økt sykeliggjøring.

God helse må være å bevare livsgleden og fungere på jobb og i hverdagslivet uansett hva vi bærer med oss av psykiske og fysiske slitasjer. Selv om vi ikke er helt på topp på noen av disse områdene, så er vi vel ikke nødvendigvis syke? Vi må endre sykdomsbegrepet og slutte å kalle alle ubehageligheter sykdom.

For en stund siden traff jeg en nybakt mor som hadde brukket benet. Med en toåring i huset i tillegg til spedbarnet lurte jeg på hvordan hun klarte å få hverdagen til å henge sammen. «Mannen min er sykmeldt», sa hun. «Hvis han er syk, kan han vel ikke hjelpe deg», svarte jeg. Selvsagt måtte mannen være hjemme i en periode fra jobben for at familien skulle fungere. Jeg ønsker at leger og arbeidsgivere får kalle slike fravær for noe annet enn sykmelding. Kan ikke samfunnet i stedet gi tillatelse til å kalle det velferdspermisjon eller «friskhetsfravær» fremfor å klassifisere det som er normalt for sykt?

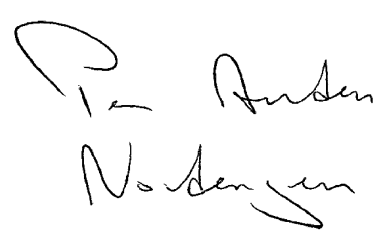

